Lam, P. Q., Tuan, V. V., \& Duong, T. T. (2020). Improve teaching capacity at private universities in Ho Chi Minh city, Vietnam according to AUN-QA, International Journal of Cognitive Research in Science, Engineering and Education (IJCRSEE), 8(3), $61-72$.

Original scientific paper

UDK:

Received: August, 25.2020.

Revised: October, 19.2020.

$378.147 .014 .5(597)$

Accepted: October, 27.2020.

doi: 10.23947/2334-8496-2020-8-3-61-72

\title{
Improve Teaching Capacity at Private Universities in Ho Chi Minh City, Vietnam According to AUN-QA
}

\author{
Phan Quoc Lam", Vo Van Tuan², Duong Thi Thanh
}

1Department of Education, Vinh University, Vinh, Vietnam e-mail: professorlam015@gmail.com; vovantuan81@yahoo.com

2Department of Education, Van Lang University, Ho Chi Minh, Vietnam e-mail: duongthithanh.info@gmail.com

\begin{abstract}
The purpose of this study was to develop an approach to assessing the potential of teachers for the possibility of introducing quality standards of the educational process according to AUN-QA in the higher education system of Vietnam. A survey of teachers and managers of 6 private universities in Ho Chi Minh City was carried out, aimed at assessing the quality of university teachers and their potential to AUN-QA standards. The number of respondents was 172 teachers and 42 managers of the studied universities. Evaluation of the survey responses was made on a 4-point Likert scale. Using the SPSS 22.0 software package, statistical processing of the results of the questionnaire survey of teachers was carried out. By means of questionnaires, an assessment of the need (urgency) and the possibility of implementing measures aimed at increasing the teaching potential was carried out. A pedagogical experiment was carried out, which involved the passage of training for teachers in order to increase the pedagogical potential: the development of the theoretical base and practical skills in the application of teaching methods, such as Teaching simulation, Teaching case studies, Learning project, Teaching by situation, Lecture, Problem solving, Teaching in groups, Practical methods, experiments, Training method, review. The experiment involved 61 teachers from Van Lang University. According to the results of the experiment, a statistically significant increase in the level of methodological knowledge of teachers and skills for their implementation was revealed. The results obtained are of practical importance and can serve as a basis for solving numerous problems of higher education in the country. They can also be used to improve the quality of educational services, the effectiveness of reforms in the education system of Vietnam.
\end{abstract}

Keywords: Vietnam, university, education, training.

\section{Introduction}

The effective functioning of the socio-economic system and the achievement of a high level of well-being of the population, as shown by the advanced experience of developed countries, is primarily ensured by improving the quality of the higher education system (Salmi, 2018). High-quality higher education that contributes to the development of the cultural and spiritual superstructure of society forms the intellectual basis of human capital as the main productive force of innovative development (Salmi, 2018). In this regard, the quality of higher education in modern conditions should be harmonized with the current needs in the field of economics, technology, science, culture, have an applied character and adapt to the volatility of the socio-economic system in the context of globalization. Back in 2005, before the universities of Vietnam, by the approval of Resolution No. 14/2005/NQ-CP On substantial and comprehensive renewal of Vietnam's tertiary education in the 2006-2020 period (Van Khai, 2005), the priority of internationalization and innovative development was determined and by the end of 2020 enter in the ranking of 200 universities in the world. The Vietnamese government pays a lot of attention to education reforms. Outdated curricula, low quality of education do not allow producing highly qualified personnel, and the country needs professionals. The rapid growth of higher education in the Asian countries has brought forth challenges in the higher education sector, including but not limited to "shortages of qualified instructional staff (and) a need to improve instructional quality" (Liu, 2016). It is considered that although quality assurance system is never built from scratch, the normal implementation process is a linear one (Shah and Nair, 2016): new tools and procedures are developed and therefore some conditions are needed in order to support organization to adapt to these new tools and procedures.

In the trend of internationalization, the task of the teaching staff must both help learners meet the integration ability and at the same time improve their applicability in their professional work. Teachers are the most significant change agent in educational reform (Nguyen, 2018; Glewwe et al., 2017). They "Corresponding author: professorlam015@gmail.com 
should improve students' transferable skills to enhance their chances of employment (Demombynes and Testaverde, 2017). According to Tran and Marginson (2018a), good teaching involves giving clear explanation through interesting lessons and providing useful and timely feedback. As rightly observed by Pham (2018b), unless teachers provide effective instruction and create classroom environment conducive to learning, students will not achieve at high levels even when essential material inputs are available and curriculum is relevant. According to Thuy Thi and Yi-Fang (2014), the sense of responsibility and high level of engagement between students and teachers makes quality assurance effective. Teacher commitment is one of the quality values in congruence among higher education stakeholders (Le and Hayden, 2017). One of the roles of the teachers is monitoring and evaluating students learning. The learning environment is positive when it is favourable for students' meaningful and productive learning. In such an environment as noted by Nhat and Bich (2017), "educational programs, materials and procedures are designed to meet the needs of each student".

The main disadvantage of Vietnam's higher education is that the standard of training does not meet the socioeconomic development criteria. If there is no drastic and successful solution, the country will lose its competitive edge in terms of standard and human capital (Tran and Marginson, 2018a).

Currently, the majority of state and private universities in Vietnam has been implementing QA activities in accordance with the regulations of the Ministry of Education and Training of Vietnam, but the effectiveness of this activity is not high has no significant impact on the improvement of training quality because it does not meet international standards on QA and is in line with the development of these schools (Le, 2016). The model and the level of QA of universities such as the AUN-QA model of the Southeast region network of universities are the best options because it conforms to the minimum international standards and corresponds to the level of the current development of higher education system in the country (Longpradit et al., 2019). AUN-QA Network is established as the ASEAN quality assurance network in higher education with the responsibility to promote quality assurance in higher education institutions, raise the quality of higher education, and collaborate with both regional and international bodies for the benefit of the ASEAN community (AUN-QA, 2020). To implement this idea, programs of the 200 best universities in the world were selected, occupying high positions in the world ranking. Over the past 10 years, educational programs based on advanced training courses have achieved their goals. In particular, courses introduced advanced training of the teaching staff, expanded scientific research, consolidated objects of international cooperation. The goal of the project is that by 2020 higher education in Vietnam must become competitive and adapted to a socialist-oriented market mechanism, and several Vietnamese universities must achieve world-class level through improving higher education quality assurance systems (Nguyen, 2017). In 2003, quality assurance through mandatory accreditation mechanism for both institutions and programmes was officially introduced into Vietnam's higher education. Several studies observed and discussed certain aspects of Vietnam's accreditation (Do et al., 2017; Nguyen, 2018; Pham, 2018a, 2018b, 2018c; Westerheijden et al., 2010).

However, the active introduction of advanced technologies in private and public universities in Vietnam is faced with the problem of unpreparedness and inconsistency of the potential of the teaching staff in the higher education system, which in turn inhibits the process of improving the quality of education. In view of this, the question of the need for didactics of the current level of the potential of teachers in the universities of Vietnam to be ready for the introduction of progressive educational technologies AUN-QA is actualized. This study was aimed at developing a toolkit for assessing the quality level of the organization of the educational and cognitive process, stimulating interest in knowledge in the educational process on the example of private universities in Ho Chi Minh City, Vietnam. Ho Chi Minh City is the locality with the highest number of private universities in the country. The subject of the research are private universities the training level of teachers of private Universities is generally low compared to requirements and compared to public schools. According to some schools, finding a teacher with a high-level teaching degree is quite difficult, especially with some specific majors, many people do not want to pursue academic titles such as the other arts and creative fields, and they consider a more practical work capacity. Another important issue of the faculty of private universities is the unbalanced teacher structure. The number of faculty members with academic titles, degrees, and experience is high in age (some retired in other schools and agencies) and less active and creative; some young teachers are creative, highly motivated but have little experience and no academic titles. That makes a large number of schools not develop, even threatened to not exist (Hanh, 2020). Therefore, improving the quality of teachers in the higher education system with measures that are scientific and in line with the practice is one of the urgent jobs. 
Lam, P. Q., Tuan, V. V., \& Duong, T. T. (2020). Improve teaching capacity at private universities in Ho Chi Minh city, Vietnam according to AUN-QA, International Journal of Cognitive Research in Science, Engineering and Education (IJCRSEE), 8(3), $61-72$.

\section{Literature review}

First requirement for internationalization higher education in Vietnam is to bring all content and learning technologies in line with world standards and level of education to advanced universities of the world (Asadullah et al., 2020; Canadian Bureau for International Education, 2017; Linh and Thuy Anh, 2018). At the same time, as noted in the draft Reform $87 \mathrm{III}$. The international contacts in the development of higher education in Vietnam, it is important to preserve all the best that has been achieved in national education, so as not to lose the identity of the nation. In the world and in Vietnam, there are many scientific works and researches on training quality and quality assurance in higher education institutions. However, no systematic and comprehensive studies on training quality assurance for private universities have been conducted by any authors (Tran, 2018). However, all studies indicate that the quality assurance of university training is an area of quality assurance. Therefore, the content, manner and process to ensure the quality of training of universities must follow the content, manner and process of quality assurance in general and at the same time suitable to the training characteristics of universities (Akareem and Hossain, 2016; Pham, 2017). The selection of a model to ensure the quality of training in accordance with the strategic objectives and conditions of each school is extremely important. AUN-QA is a training quality assurance model that has certain advantages for private universities in Ho Chi Minh City (Yang, 2017). By many scientific and appropriate research methods, the actual quality of training according to AUN-QA has been clarified according to 11 standards. Most of the standards are rated by the survey respondents as "good". Some criteria to evaluate at the level of "good", including: Quality of teaching staff; Infrastructure and equipment; Quality improvement solutions; Quality of graduates (Masino and Niño-Zarazúa, 2016).

The scientific literature contains many works confirming the directly proportional interdependence between the quality of higher education and the level of socio-economic development of the country (Salmi, 2018; Kromydas, 2017; Lehmann et al., 2020; Sánchez and Singh, 2018). The quality of education reflects a social category that reflects performance (Madani, 2019; Crosling, 2017; Nhan and Nguyen, 2018), the current state and its compliance with social needs in the process of formation, development of professional and cultural competencies of students in the educational system (Nguyen and Tran, 2018). This category in the normative legal and modern pedagogical literature is considered from the point of view of the unity of teaching as a process (Ng, 2015; Pitiyanuwat et al., 2017) and education as a result $(\mathrm{Ng}, 2015)$. Consequently, the quality of education should be considered on an individual-personal level, taking into account the real needs and capabilities of the subjects of the educational process. The quality of education is inextricably linked with pedagogical technologies, since in modern conditions, various audio, hardware and software tools have been actively introduced into the pedagogical and educational process to improve the quality of the educational process (Abd and Behadili, 2019; Ali et al., 2018; Burbules et al., 2020). Productive author's methods were optimistic and became almost a panacea for ineffective learning in the higher education system (Lucander and Christersson, 2020; Burbules et al., 2020; Janssen et al., 2019). Many studies show that the use of active learning methods can create conditions for translating the acquired knowledge into an applied form and increase the motivation of students (Rizkallah and Seitz, 2017; López et al., 2019). Innovative pedagogical technologies create new learning opportunities (Burbules et al., 2020). Opportunities for personalized learning are emerging, new models of collaboration are emerging, and the range of learning innovative and engaging to learners strategies expands. In addition to the obvious advantages of modern technologies in education, there are also disadvantages "pitfalls" that teachers face when implementing. It should be noted that the systematic approach gradually led to a general setting of pedagogical technology: to solve didactic problems within the framework of the management of the educational process with precisely defined goals, the achievement of which is difficult to clearly describe and define in each specific case (Nasim et al., 2019). This will lead to many problems in improving the quality of the educational process, because students do not have equal access to pedagogical technological resources (Burbules et al., 2020). Too active implementation and without proper experience demagogic technologies can adversely affect the development of students' communication skills and social interaction (Nasim et al., 2019). Teachers lack digital literacy skills, which makes it impossible to hinder the development of innovations in education, etc. (Nasim et al., 2019; Orakcl et al., 2020).

Scientists emphasize that the main link in ensuring the quality of education is the teacher. There is no doubt that every teacher must understand the role that he plays in shaping the personality of a student, a full member of the modern information society. The teacher must be ready to use new teaching and information technologies and technical means in the teaching and development of students. Therefore, improving the professionalism of the teaching staff will be one of the urgent tasks of the innovative development of education. To do this effectively, firstly, university administration must have a teaching 
staff development orientation based on a reasonable model and an adaptive model. Universities have different levels of potential to improve the quality of the educational process (Bui et al., 2020; Tran et al., 2017; Tran and Marginson, 2018b; Tran and Nguyen, 2018) and those with a low level of potential cannot use on the first stages are too progressive pedagogical technology. Therefore, within the framework of this study, using the example of Ho Chi Minh City private universities that have a low level of potential for the development of education quality today, the possibilities of introducing the AUN-QA model of the network of universities in Southeast Asia are being evaluated. This is a model for ensuring minimum international standards, consistent with the current level of development of these private universities.

\section{Materials and Methods}

The implementation of the research objectives consisted of 2 parts. Part 1 is aimed at assessing the compliance of the quality of university teachers and their potential with the AUN-QA standards; assessing the need, the possibility of implementing measures to improve pedagogical potential. The second part of the study was a pedagogical experiment aimed at increasing the level of teaching potential in the framework of AUN-QA and assessing its effectiveness. The methodological basis for obtaining quantitative estimates in both cases was the questionnaire method.

The survey was carried out in 3 stages. At the $1^{\text {st }}$ stage (September-October 2019), 381 managers and teachers at 6 private universities in Ho Chi Minh City (Van Lang University, Hutech University, Ho Chi Minh City University of Foreign Languages-Information Technology, Hong Bang International University, Van Hien University, University of Economics Ho Chi Minh City) received questionnaires aimed at assessing the compliance of the quality of university teachers with the AUN-QA standards. Respondents sent back 214 complete questionnaires. Participation in the survey was voluntary, and the results were anonymous. The representativeness of the survey results is evidenced by the size of the sample population, which exceeds the minimum size requirements - 100 people (Hashim, 2010). The minimum sample size is determined based on a significance level of 0.1 , which ensures the accuracy and reliability of the survey results (Kim, 2015).

The representativeness of the sample is also evidenced by the representation of 6 universities, there are no statistically significant differences between the assessments of the respondents. These differences were assessed by the Student's t-test, the empirical values of which (0.67-1.11) do not exceed the tabular values 1.992-1.998 at $p=0.05$. Thus, the results obtained are representative of the entire private higher education system in Ho Chi Minh City. The structure of the respondents is shown in Table 1.

Table 1

Number of subjects participates in the survey

\begin{tabular}{clcc}
\hline No & Subjects & Quantity & Rate (\%) \\
\hline 1 & Managers & 42 & 19.6 \\
2 & Teachers & 172 & 80.4 \\
& Total & 214 & 100 \\
\hline
\end{tabular}

The respondents were asked to rate the quality of university teachers according to GV standards system according to AUN-QA. According to this system of standards, one of the aspects of assessing the quality of higher education is the quality of the organization of the educational process and the development of the teaching staff (Do, 2018; Hoang et al., 2018; Nguyen et al., 2016) in the areas indicated in Table. 2. Compliance with these fundamental standards is a prerequisite for the effectiveness of higher education. The questionnaire is designed on the 4-point Likert scale, according to which categories are used to evaluate the questionnaire's questions completely agree, agree, disagree, strongly disagree (Lipovetsky, 2017). The score increases as the level of agreement increases.

The reliability of the questionnaire was assessed based on the scores of the respondents using Cronbach's Alpha coefficient in Statistica 12.0 (Table 2). 
Lam, P. Q., Tuan, V. V., \& Duong, T. T. (2020). Improve teaching capacity at private universities in Ho Chi Minh city, Vietnam according to AUN-QA, International Journal of Cognitive Research in Science, Engineering and Education (IJCRSEE), 8(3), 61-72.

Table 2

Indicators of the questionnaire's reliability

\begin{tabular}{llc}
\hline No & \multicolumn{1}{c}{ Questionnaire's item } & Cronbach's alpha value \\
\hline 1 & $\begin{array}{l}\text { Recruitment, appointment, and promotion criteria are well defined and widely } \\
\text { disseminated }\end{array}$ & 0.87 \\
2 & $\begin{array}{l}\text { There is a plan to develop teachers' staff (succession, promotion, promotion, re- } \\
\text { assignment, termination, and retirement) to meet training, research and to serve the } \\
\text { community. }\end{array}$ & 0.89 \\
3 & $\begin{array}{l}\text { The ratio of teachers/students and workloads is measured and monitored to improve } \\
\text { the quality of education, research and to serve the community. }\end{array}$ \\
4 & $\begin{array}{l}\text { Recruitment and selection criteria for appointment, assignment, and promotion, } \\
\text { including ethical and academic freedom standards, are well-defined and disseminated }\end{array}$ & 0.91 \\
to stakeholders. & 0.90 \\
5 & $\begin{array}{l}\text { The competence of teachers is clearly defined and evaluated } \\
6\end{array} \quad \begin{array}{l}\text { The need for training and professional development for teachers is identified and } \\
\text { appropriate activities are implemented to meet these needs. }\end{array}$ & 0.90 \\
7 & $\begin{array}{l}\text { The management according to the results of teachers' work (including reward and } \\
\text { recognition) is implemented to encourage and support training, scientific research, } \\
\text { and community service activities. }\end{array}$ & 0.88 \\
8 & $\begin{array}{l}\text { The types and quantity of research activities of teachers are clearly defined, } \\
\text { monitored and matched to improve quality } \\
\text { Total }\end{array}$ & 0.90 \\
\hline
\end{tabular}

For the questions of the questionnaire No 3-5, 8 the value of the Cronbach's alpha, calculated according to the respondents' estimates, is higher than the general one according to the questionnaire. This means that eliminating these questions will improve the reliability of the questionnaire. On the other hand, excluding half of the questions will significantly reduce the information content. Therefore, when processing the results, we used the answers to all the questions in the questionnaire. The reliability of the questionnaire is evidenced by the general coefficient of Cronbach's alpha, the value of which is 0.89 .

In addition to assessing the quality of teachers at this stage of the study, respondents were asked to assess the urgency and feasibility of implementing activities aimed at increasing teaching potential (quality of teachers). To determine the level of urgency and the possibility of implementing measures, based on the average estimates of the respondents in the sample, the range of possible estimates (Abd and Behadili, 2019, 4) is divided into 4 equal segments (Lipovetsky, 2017). Formed levels are given in Table 3.

Table 3

Convention for coding survey data

\begin{tabular}{ccc}
\hline Average score & Necessity & Possibility \\
\hline $3.26-4$ & Very urgent & Very feasible \\
$2.51-3.25$ & Necessary & Feasibility \\
$1.76-2.50$ & Less urgent & Less feasible \\
$1-1.75$ & Not urgent & Impossible \\
\hline
\end{tabular}

Exploration results are processed by descriptive statistics: percentage (\%); average score and standard deviation; t-test. SPSS software version 22.0 is used to process the results statistically.

The $2^{\text {nd }}$ and $3^{\text {rd }}$ stages of the questionnaire were aimed at assessing the effectiveness of the pedagogical experiment aimed at training to improve teaching capacity for teachers under AUN-QA. The second stage was carried out in October 2019 - before the start of the experiment, the third - in January 2020 following the results of the experiment. The experiment included 61 teachers of Van Lang University with seniority working mainly for more than 15 years (80.5\%), teaching seniority of the University on average is 8.91 years. Due to the small size of the sample, the participants in the experiment were not assigned to the control and experimental groups. Therefore, during the experiment period, the influence of factors contributing to the development of teachers was excluded for the participants, with the exception of the activities provided for by the experiment. Before the start of the experiment and after its completion, a survey was carried out aimed at assessing the methodological knowledge of teachers and the level of practical skills in the implementation of teaching methods according to the above-mentioned 4-point 
Likert scale. The effectiveness of the experiment was evaluated based on a comparison of the average estimates for the sample obtained after the end of the experiment and the results at the beginning of the experiment. The statistical significance of the differences was assessed using the Student's t-test at a significance level of 0.05. The experiment implied a 2-month training (during November-December 2019) among university teachers, which involved performing tasks aimed at developing the theoretical base and practical skills of teachers in the application of such techniques as teaching simulation, teaching case studies, learning project, teaching by situation, lecture, problem solving, teaching in groups, practical methods, experiments, training method, review.

\section{Results}

The results of the questionnaire survey of university professors and managers regarding quality of teachers at private universities are shown in Table 4.

Table 4

The actual quality of teachers at private universities in Ho Chi Minh City

\begin{tabular}{|c|c|c|c|c|c|c|c|c|}
\hline \multirow[b]{2}{*}{ No } & \multirow[b]{2}{*}{ Contents } & \multicolumn{2}{|c|}{ General } & \multicolumn{2}{|c|}{ Managers } & \multicolumn{2}{|c|}{ Teachers } & \multirow[t]{2}{*}{$p$} \\
\hline & & $\begin{array}{c}\text { Average } \\
\text { score (GPA) }\end{array}$ & $\begin{array}{c}\text { Standard } \\
\text { deviation (SD) }\end{array}$ & GPA & SD & GPA & SD & \\
\hline 1 & $\begin{array}{l}\text { Recruitment, appointment, and promotion } \\
\text { criteria are well defined and widely } \\
\text { disseminated }\end{array}$ & 3.30 & 0.787 & 3.20 & 0.857 & 3.31 & 0.776 & * \\
\hline 2 & $\begin{array}{l}\text { There is a plan to develop teachers' staff } \\
\text { (succession, promotion, promotion, re- } \\
\text { assignment, termination, and retirement) to } \\
\text { meet training, research and to serve the } \\
\text { community. }\end{array}$ & 3.34 & 0.757 & 3.18 & 0.800 & 3.37 & 0.749 & 0.04 \\
\hline 3 & $\begin{array}{l}\text { The ratio of teachers/students and workloads } \\
\text { is measured and monitored to improve the } \\
\text { quality of education, research and to serve the } \\
\text { community. }\end{array}$ & 3.06 & 0.847 & 2.84 & 0.955 & 3.10 & 0.826 & 0.04 \\
\hline 4 & $\begin{array}{l}\text { Recruitment and selection criteria for } \\
\text { appointment, assignment, and promotion, } \\
\text { including ethical and academic freedom } \\
\text { standards, are well-defined and disseminated } \\
\text { to stakeholders. }\end{array}$ & 3.20 & 0.825 & 3.00 & 0.969 & 3.23 & 0.799 & 0.04 \\
\hline 5 & $\begin{array}{l}\text { The competence of teachers is clearly defined } \\
\text { and evaluated }\end{array}$ & 3.21 & 0.772 & 3.02 & 0.869 & 3.24 & 0.754 & 0.04 \\
\hline 6 & $\begin{array}{l}\text { The need for training and professional } \\
\text { development for teachers is identified and } \\
\text { appropriate activities are implemented to meet } \\
\text { these needs. }\end{array}$ & 3.29 & 0.793 & 3.16 & 0.817 & 3.31 & 0.789 & 0.04 \\
\hline 7 & $\begin{array}{l}\text { The management according to the results of } \\
\text { teachers' work (including reward and } \\
\text { recognition) is implemented to encourage and } \\
\text { support training, scientific research, and } \\
\text { community service activities. }\end{array}$ & 3.24 & 0.788 & 03.08 & 0.966 & 3.28 & 0.756 & 0.04 \\
\hline 8 & $\begin{array}{l}\text { The types and quantity of research activities of } \\
\text { teachers are clearly defined, monitored and } \\
\text { matched to improve quality }\end{array}$ & 3.22 & 0.813 & 3.10 & 0.863 & 3.24 & 0.805 & 0.04 \\
\hline & Gene & 3.23 & 0.654 & 3.07 & 0.771 & 3.26 & 0.632 & 0.04 \\
\hline
\end{tabular}

Note: $p^{*}>0.05$

Poll results show that:

- Overall quality of the teachers is assessed at a good level by the surveyed subjects (GPA = 3.23; $S D=0.665)$. However, there was a difference in the assessment of the two target groups. In which: group 
of managers evaluate at the level of "good" (GPA $=3.07$; $S D=0.771)$; group of teachers evaluate at the level of "good" (GPA $=3.26$; SD $=0.632$ ); $p$-value in the t-test test $=0.04<0.05$. The differences in the estimates obtained are statistically significant according to the Student's t-test at a significance level of 0.05 .

- In a total of 8 criteria to evaluate the quality of the teachers, there are $3 / 8$ criteria for the quality of the team that is rated by the surveyed audience as a "good" rating (average score $>3.25$ ); $5 / 8$ criteria at the "good" ranking level.

- Criteria "there is a plan to develop teachers (succession, promotion, reassignment, contract termination, retire) to meet training and research needs and serving the community "has the highest GPA of 8 criteria (GPA $=3.34$; SD $=0.757$ ), corresponding to the" good "rating.

- Criteria "Teacher/Student ratio and workload measured and monitored to improve teaching, research and community service quality" have the lowest average score of the 8 criteria (average score $=3.06$; standard deviation $=0.847$ ), corresponding to a "good" rating level. This is a big problem in personnel management of PUs.

- Criteria related to "recruitment and selection criteria for appointment, assignment, and promotion, including ethical and academic freedom standards, which are clearly defined and disseminated to relevant parties "have the second-lowest average score out of 8 criteria (GPA $=3.20 ; \mathrm{SD}=0.825$ ), corresponding to a" good "rating. In the evaluation criteria of the Ministry of Education and Training or from the views such as overall quality management, ISO ... the issue of "academic freedom" of teachers is rarely mentioned. But for the AUN-QA approach, this is one of the important criteria. For teachers to be able to "academic freedom", teachers not only need to constantly strive to improve their capacity and update their knowledge but also need the support and legal corridor of managers. That is also showing "autonomy" in higher education (Pham, 2018c). Although, this criterion is ranked at "fairly" but in practice, "academic freedom" of teachers of PUs is more highly appreciated than teachers of public universities. One teacher commented in the in-depth interview results as follows: "We teachers have the right to present much knowledge outside the curriculum. Because knowledge is always new, the textbooks we use are mainly written by teachers from other schools - public universities many years ago. As soon as you get up, students will listen and how to ensure the quality".

- Differences in the evaluation of the 2 target groups included in $7 / 8$ criteria $(p=0.04<0.05)$. In particular, the group of managing officers has a lower average score than teachers. When learning more by the method of an in-depth interview, they were answered: "In the text, it is clearly stated that the problem of teacher capacity assessment, recruitment or appointment ... but in practice, the implementation is not always and consistently applying rigid regulations."

In summary, the survey results show that the quality of faculty staff of PUs in Ho Chi Minh City has achieved certain results but there is a need to have more advanced management measures to help faculty staff to grow in number as well as quality and professional competence. The issues of academic freedom, regulations, and support for teachers to implement scientific research tasks and teacher capacity assessment activities need to be completed.

Of course, the above assessments are only the beginning and only a subjective opinion, at the general level of the two groups of subjects. To accurately assess, comprehensive studies are needed on approaches, content, and methods. However, the results also show that to improve the quality of training, the PUs of HCMC must improve the quality of the teachers.

The need to carry out activities to improve the teaching capacity of the respondents was assessed as "Very urgent". There is also a high probability of implementation of measures to improve teaching potential within the framework of AUN-QA (Table 5).

Table 5

Correlated results on urgency and feasibility of the proposed measure

\begin{tabular}{lllllll}
\hline \multirow{2}{*}{ No } & \multirow{2}{*}{ Solutions } & \multicolumn{3}{c}{ Necessity } & \multicolumn{3}{c}{ Feasibility } & \multirow{2}{*}{$\mathrm{p}$} \\
\cline { 3 - 5 } & GPA & SD & GPA & SD & \\
\hline 1 & $\begin{array}{l}\text { Organise training to improve teaching capacity for teachers } \\
\text { under AUN-QA }\end{array}$ & 3.33 & 0.70 & 3.21 & 0.79 & 0.12 \\
\hline
\end{tabular}

Table 5 shows that the proposed measures are urgent and similarly feasible, in this connection, a pedagogical experiment was carried out aimed at assessing the effectiveness of measures to train university teachers. The experiment is a training aimed at increasing the level of theoretical and practical knowledge of teaching methods on the part of teachers. The experimental results are shown in Tables 6 , 7. 
Lam, P. Q., Tuan, V. V., \& Duong, T. T. (2020). Improve teaching capacity at private universities in Ho Chi Minh city, Vietnam according to AUN-QA, International Journal of Cognitive Research in Science, Engineering and Education (IJCRSEE), 8(3), 61-72.

Table 6

Awareness of teaching methods before and after the experiment

\begin{tabular}{|c|c|c|c|c|c|c|}
\hline \multirow{2}{*}{ No } & \multirow{2}{*}{ Contents } & \multicolumn{2}{|c|}{ Before the experiment } & \multicolumn{2}{|c|}{ After the experiment } & \multirow{2}{*}{$\mathrm{p}$} \\
\hline & & GPA & $S D$ & GPA & $\mathrm{SD}$ & \\
\hline 1 & Teaching simulation & 2.75 & 0.23 & 3.47 & 0,13 & ** \\
\hline 2 & Teaching case studies & 2.97 & 0.31 & 3.40 & 0,23 & ** \\
\hline 3 & Learning project & 2.99 & 0.28 & 3.17 & 0,12 & * \\
\hline 4 & Teaching by situation & 2.86 & 0.29 & 3.22 & 0.17 & ** \\
\hline 5 & Lecture & 2.89 & 0.36 & 3.21 & 0,16 & ** \\
\hline 6 & Problem solving & 2.90 & 0.35 & 3.29 & 0.22 & ** \\
\hline 7 & Teaching in groups & 3.05 & 0.31 & 3.10 & 0.26 & * \\
\hline 8 & Practical methods, experiments & 3.02 & 0.22 & 3.22 & 0,13 & ** \\
\hline 9 & Training method, review & 2.91 & 0.11 & 2.97 & 0,12 & * \\
\hline \multicolumn{2}{|c|}{ General } & 2.91 & 0.17 & 3.23 & 0.12 & ** \\
\hline
\end{tabular}

Conventions: $p^{*}>0.05 ; p^{* *}<0.05$

The results show that: GPA about the methodological knowledge of the teachers participating in experiments has been improved after the experiment in a significant way (before experiment: GPA $=2.91$; $\mathrm{SD}=0.17$; after experiments: $\mathrm{GPA}=3.23 ; \mathrm{SD}=0.12 ; \mathrm{p}<0.05$ ).

$6 / 9$ teaching methods have significantly higher post-impact scores than meaningful pre-impact scores. However, there are 3 post-empirical baseline criteria higher than before, but the $p$ value in the test is $>0.05$, the difference is not significant. Those are 3 criteria: Learning project; Teaching in groups; Training method, review.

Statistics of actual skills applied in practice on teaching methods before and after the test are presented in Table 7.

Table 7

Skills of practicing teaching methods before and after experiments

\begin{tabular}{|c|c|c|c|c|c|c|}
\hline \multirow{2}{*}{ No } & \multirow{2}{*}{ Contents } & \multicolumn{2}{|c|}{$\begin{array}{l}\text { Before the } \\
\text { experiment }\end{array}$} & \multicolumn{2}{|c|}{ After the experiment } & \multirow{2}{*}{ Sig } \\
\hline & & GPA & SD & GPA & SD & \\
\hline 1 & Teaching simulation & 2.79 & 0.54 & 3.26 & 0,34 & $* *$ \\
\hline 2 & Teaching case studies & 2.88 & 0.45 & 3.35 & 0,44 & $* *$ \\
\hline 3 & Learning project & 2.58 & 0.33 & 3.27 & 0,36 & ** \\
\hline 4 & Teaching by situation & 2.35 & 0.41 & 3.13 & 0,38 & $* *$ \\
\hline 5 & Lecture & 2.79 & 0.44 & 3.35 & 0,22 & ** \\
\hline 6 & Problem solving & 2.94 & 0.36 & 3.19 & 0,33 & $* *$ \\
\hline 7 & Teaching in groups & 2.73 & 0.44 & 3.08 & 0,44 & $* *$ \\
\hline 8 & Practical methods, experiments & 2.91 & 0.311 & 2.99 & 0,23 & $* *$ \\
\hline 9 & Training method, review & 2.82 & 0.35 & 2.89 & 0,29 & $* *$ \\
\hline \multicolumn{2}{|c|}{ General } & 2,76 & 0.24 & 3.16 & 0.26 & $* *$ \\
\hline
\end{tabular}

The test results show that: The test scores on skills of implementing teaching methods of the teachers participating in the experiment have been significantly improved after the experiment (before 

61-72.

experiment: $\mathrm{GPA}=2.76 ; \mathrm{SD}=0,24$; after experiment: $\mathrm{GPA}=3.16$; $\mathrm{SD}=0.26 ; p<0.05$ ).

In summary, the awareness and skills of teaching methods of teachers have post-impacted post average higher than impacted pre-impact significantly.

The results of exploraation and testing have been carried out showing that measures to foster capacity building for teachers of Private Universities in HCM city that the author proposed are necessary, feasible and effective.

\section{Discussion}

Within the framework of this study, a methodological approach was proposed to diagnose the need (urgency) and the objective possibility of practical implementation of innovative pedagogical technologies and activities in accordance with the AUN-QA standards, aimed at increasing the teaching potential in universities with a low level of quality of the educational process. The developed approach, in contrast to the existing ones (Do, 2018; Hoang et al., 2018; Nguyen et al., 2016), in the modern literature makes it possible to obtain an objective assessment of the conditions for improving the quality of the educational process. It allows you to determine the most suitable pedagogical conditions and technologies that correspond to the current level of pedagogical potential, resource capabilities of the university, and also takes into account the existing model of the organization of the educational process. The advantages of the proposed approach to assessing the quality of teachers, in contrast to earlier developments in the scientific literature (Akareem and Hossain, 2016; Yang, 2017; Lucander and Christersson, 2020; Burbules et al., 2020) is that the resulting assessment indicator is presented as two types of variables: quantitative, expressed through scores and their mean values, and categorical, reflecting the level. Scoring provides accuracy and allows you to analyze small changes in estimates over time or to assess differences between study groups, even when the categorical variable remains unchanged. The categorical variable provides a convenient way to interpret the results. The use of a 4-point Likert scale for assessing grades avoids the effect of gravitation towards a neutral middle position, according to which, when giving marks, the respondent prefers a neutral, middle position (average score), which distorts the results obtained. With a 4-point scale, there is no neutral assessment option.

The obtained results allowed to conclude that teachers need to be fostered and improved with professional measures such as training to improve their qualifications, using information technology for teaching and applying advanced forms. Progressing in the training of teachers, promoting scientific research, fostering in the direction of researching and improving foreign language skills. Specifically: fostering teachers to actively participate in advanced forms of training, online training, to both improve their qualifications and approach new teaching models, thereby helping them supplement their knowledge, diversify forms of teaching. In the coming time, online teaching models will be applied in higher education, such as E-learning; B-learning; videoconferencing. At the same time, it is necessary to expand the model of linkage between the school - the manager - the entrepreneur so that based on the link, the teachers can directly participate in the process of practicing and working in businesses, Enterprises can send highly skilled employees to the training process. Thus, new teachers have conditions to innovate, create and associate theory with practice. In addition, it is necessary to promote the capacity of scientific research for university teachers so that they can apply modern methods to teaching.

Attention should be paid to developing teaching capacity, including specific contents such as curriculum development at the subject level; determine the learning goals of the subject and each unit of study of students; identify the appropriate content to achieve the set goals; identify appropriate learning and teaching methods to convey content and reach goals; identify appropriate evaluation methods to motivate learners and properly assess learners' qualifications (Nguyen and Tran, 2018). Strengthen the ability to use positive teaching methods, which are appropriate with their own expertise, such as: situational teaching, group discussions, discoveries, simulations, projects ... transmit; problem solving and decision-making capacity; conflict management and negotiation capacity; the ability to constantly learn and develop oneself; capacity to use modern equipment and facilities in teaching (managing resources, data on the internet, proficient use of new technology facilities for teaching process ...).

Gradually perfect the standards of teacher morality and constantly cultivate political qualities. Each teacher must self-study and train in order to have a high professional capacity, grasp new achievements of science and technology in order to promptly apply them in teaching work; be able to use at least one foreign language fluently, mainly and most importantly English; have scientific research capabilities in their field of expertise. At the same time, the authorities need to develop and complete a separate set of criteria for university teachers. On that basis, higher education institutions develop a development 
Lam, P. Q., Tuan, V. V., \& Duong, T. T. (2020). Improve teaching capacity at private universities in Ho Chi Minh city, Vietnam according to AUN-QA, International Journal of Cognitive Research in Science, Engineering and Education (IJCRSEE), 8(3), $61-72$.

strategy for faculty members to suit the needs of the unit through many forms of training.

\section{Conclusion}

The conducted research allowed to conclude the following. Facing the impact of the industrial revolution 4.0 taking place in many fields and in order to meet the requirements, higher education in Vietnam needs to quickly change training methods to suit the development trend. As shown by the research, improving teaching capacity for teachers is an important task that the management in private universities must perform to improve the quality of training and quality assurance according to AUN-QA. It has been empirically established that in modern conditions, the pedagogical potential of private universities in Vietnam has a sufficient level of teacher qualifications and pedagogical conditions correspond to the possibilities of introducing quality standards in the educational process in accordance with AUN-QA. It was determined that the average assessment of the quality of teachers is 3.23 out of 4 maximum. At the same time, the assessments of managers are higher than those of the teachers. The developed system of measures aimed at increasing the teaching potential and the quality level of the educational process in accordance with the AUN-QA standards is an essential condition for increasing the efficiency and quality of the higher education system in Vietnam today. In particular, organising the capacity building activities for teachers is one of the urgent, basic and long-term jobs. To train teachers effectively, the organisation of training must be based on the needs of the teachers and the requirements of AUN-QA.

It should be noted that the results in cancers of this research study were obtained from a sequestered sample of respondents. Therefore, the identified patterns of development of pedagogical potential and the level of quality of the educational process can only be used in the pedagogical practice of private universities in Ho Chi Minh City, Vietnam. In addition, this article did not consider the individual characteristics of teachers in the studied universities in the process of introducing advanced educational standards and pedagogical technologies in accordance with AUN-QA. These questions require fundamental study and will become our priority for further scientific research.

\section{Acknowledgments}

We would like to thank the following companies for their assistance with the collection of our data: Van Lang University, Van Hien University, Nguyen Tat Thanh University, Hong Bang University, EconomicFinancial University, Ho Chi Minh City University of Technology.

We would like to express our very great appreciation to Doctor Tran Manh Ha, vice-president of Hong Bang University and Doctor Nguyen Manh Hung, college board vice-president of Nguyen Tat Thanh University for their valuable and constructive suggestions during the planning and development of this research paper.

\section{Conflict of interests}

The authors declare no conflict of interest.

\section{References}

Abd, M. S., \& Behadili, S. F. (2019). Recognizing job apathy patterns of Iraqi higher education employees using data mining techniques. Journal of Southwest Jiaotong University, 54(4). https://doi.org/10.35741/issn.0258-2724.54.4.30

Akareem, H. S., \& Hossain, S. Sh. (2016). Determinants of education quality: what makes students' perception different? Open Review of Educational Research, 3(1), 52-67. https://doi.org/10.1080/23265507.2016.1155167

Ali, S. H., Alaa, K. H., \& Wid, A. A. (2018). Analyzing students' answers using association rule mining based on feature selection. Journal of Southwest Jiaotong University, 53(5). Retrieved from https://jsju.org/index.php/journal/article/view/236

Asadullah, M. N., Perera, L. D. H., \& Xiao, S. (2020). Vietnam's extraordinary performance in the PISA assessment: A cultural explanation of an education paradox. Journal of Policy Modeling. https://doi.org/10.1016/j.jpolmod.2020.02.007

AUN-QA. (2020). ASEAN University Network-Quality Assurance. Retrieved from http://www.aun-qa.org/briefintroduction

Bui, T. A., Nguyen, C. V., Nguyen, K. D., Nguyen, H. H., \& Pham, P. T. (2020). The effect of tuition fee reduction and education subsidy on school enrollment: Evidence from Vietnam. Children and Youth Services Review, 108, 104536. https://doi. org/10.1016/j.childyouth.2019.104536

Burbules, N. C., Fan, G., \& Repp, P. (2020). Five trends of education and technology in a sustainable future. Geography and Sustainability, 1(2), 93-97. https://doi.org/10.1016/j.geosus.2020.05.001

Canadian Bureau for International Education. (2017). Vietnam: Insights from an international collaboration mission. Retrieved from https://cbie.ca/wp-content/uploads/2016/05/MarketReport.pdf

Crosling, G. (2017). Chapter 8 - Quality assurance and quality enhancement in Malaysian higher education. In M. Shah \& Q.

www.ijcrsee.com 
Lam, P. Q., Tuan, V. V., \& Duong, T. T. (2020). Improve teaching capacity at private universities in Ho Chi Minh city, Vietnam according to AUN-QA, International Journal of Cognitive Research in Science, Engineering and Education (IJCRSEE), 8(3), $61-72$.

T. N. Do (Eds.), The Rise of Quality Assurance in Asian Higher Education (pp. 127-141). Chandos Publishing. https:// doi.org/10.1016/B978-0-08-100553-8.00004-5

Demombynes, G., \& Testaverde, M. (2017). Employment structure and returns to skill in Vietnam: estimates using the labor force survey. Washington, DC: World Bank. Retrieved from https://openknowledge.worldbank.org/handle/10986/29458

Do, Q. T. N. (2018). Current perspectives on internationalisation of quality assurance at the institutional level. In L. T. Tran \& S. Marginson (Eds.), Internationalisation in Vietnamese Higher Education (pp. 43-54). Cham: Springer. https://doi. org/10.1007/978-3-319-78492-2_3

Do, Q. T. N., Pham, H. T., \& Nguyen, K. D. (2017). Chapter 12 - Quality assurance in the Vietnamese higher education: A topdown approach and compliance-driven QA. In M. Shah \& Q. T. N. Do (Eds.), The Rise of Quality Assurance in Asian Higher Education (pp. 191-207). Chandos Publishing. https://doi.org/10.1016/B978-0-08-100553-8.00005-7

Glewwe, P., Krutikova, S., \& Rolleston, C. (2017). Do schools reinforce or reduce learning gaps between advantaged and disadvantaged students? Evidence from Vietnam and Peru. Economic Development and Cultural Change, 65(4), 699739. https://doi.org/10.1086/691993

Hanh, N. D. (2020). A review of issues of quality assurance and quality accreditation for higher education institutions and the situation in Vietnam. Accreditation and Quality Assurance, 25, 273-279. https://doi.org/10.1007/s00769-020-01439-3

Hashim, Y. (2010). Determining sufficiency of sample size in management survey research activities. International Journal of Organisational Management and Entreprenuership Development, 6, 119-130. Retrieved from https://www. researchgate.net/publication/259822166_DETERMINING_SUFFICIENCY_OF_SAMPLE_SIZE_IN_MANAGEMENT_ SURVEY_RESEARCH_ACTIVITIES

Hoang, L., Tran, L. T., \& Pham, H. H. (2018). Vietnamese government policies and practices in internationalisation of higher education. In L. T. Tran \& S. Marginson (Eds.), Internationalisation in Vietnamese Higher Education (pp. 19-42). Cham: Springer. https://doi.org/10.1007/978-3-319-78492-2_2

Janssen, E. M., Mainhard, T., Buisman, R. S. M., Verkoeijen, P. P. J. L., Heijltjes, A. E. G., van Peppen, L. M., \& Gog, T. (2019). Training higher education teachers' critical thinking and attitudes towards teaching it. Contemporary Educational Psychology, 58, 310-322. https://doi.org/10.1016/j.cedpsych.2019.03.007

Kim, J. (2015). How to choose the level of significance: a pedagogical note. Retrieved from https://mpra.ub.uni-muenchen. de/66373/1/MPRA_paper_66373.pdf

Kromydas, T. (2017). Rethinking higher education and its relationship with social inequalities: past knowledge, present state and future potential. Palgrave Communications, 3, 1. https://doi.org/10.1057/s41599-017-0001-8/

Le, Q. A. (2016). The impact of globalisation on the reform of higher education in Vietnam. International Journal of Business and Economic Affairs, 1(1), 29-35. https://doi.org/10.24088/ijbea-2016-11005

Le, T. K. A., \& Hayden, M. (2017). The road ahead for the higher education sector in Vietnam. Journal of International and Comparative Education, 6(2), 77-89. https://doi.org/10.14425/jice.2017.6.2.77

Lehmann, E. E., Meoli, M., Paleari, S., \& Stockinger, S. A. E. (2020). The role of higher education for the development of entrepreneurial ecosystems. European Journal of Higher Education, 10(1), 1-9. https://doi.org/10.1080/21568235.20 20.1718924

Linh, V. H., \& Thuy Anh, N. (2018). Analysis of access and equity in higher education system in Vietnam. VNU Journal of Science: Policy and Management Studies, 34(4), 65-80. https://doi.org/10.25073/2588-1116/vnupam.4163

Lipovetsky, S. (2017). Factor analysis by limited scales: which factors to analyze? Journal of Modern Applied Statistical Methods, 16(1), 233-245. https://doi.org/10.22237/jmasm/1493597520

Liu, S. (2016). Quality assurance and institutional transformation: The Chinese experience. Singapore: Springer. https://doi. org/10.1007/978-981-10-0789-7

Longpradit, P., Chansaengsee, S., Niramitchainont, P., \& Leksansern, A. (2019). Evaluation of the effectiveness of AUN-QAbased course learning outcomes: a case study in a management information system course at Mahidol University. Humanities, Social Sciences and Arts, 12(5), 381-399. Retrieved from https://he02.tci-thaijo.org/index.php/Veridian-EJournal/article/view/197789

López, Á. R., Souto, J. E., \& Noblejas, M. L. A. (2019). Improving teaching capacity to increase student achievement: The key role of communication competences in higher education. Studies in Educational Evaluation, 60, 205-213. https://doi. org/10.1016/j.stueduc.2018.10.002

Lucander, H., \& Christersson, C. (2020). Engagement for quality development in higher education: a process for quality assurance of assessment. Quality in Higher Education, 26(2), 135-155. https://doi.org/10.1080/13538322.2020.176 1008

Madani, R. (2019). Analysis of educational quality, a goal of education for all policy. Higher Education Studies, 9, $100-109$. https://doi.org/10.5539/hes.v9n1p100

Masino, S., \& Niño-Zarazúa, M. (2016). What works to improve the quality of student learning in developing countries? International Journal of Educational Development, 48, 53-65. https://doi.org/10.1016/j.jijedudev.2015.11.012

Nasim, K., Sikander, A., \& Tian, X. (2019). Twenty years of research on total quality management in higher education: a systematic literature review. Higher Education Quarterly, 74(1), 75-97. https://doi.org/10.1111/hequ.12227

$\mathrm{Ng}$, P. T. (2015). What is quality education? How can it be achieved? The perspectives of school middle leaders in Singapore. Educational Assessment, Evaluation and Accountability, 27, 307-322. https://doi.org/10.1007/s11092-015-9223-8

Nguyen, D. P., Vickers, M., Ly, T. M. C., \& Tran, M. D. (2016). Internationalizing higher education (HE) in Vietnam: Insights from higher education leaders - An exploratory study. Education + Training, 58(2), 193-208. https://doi.org/10.1108/ ET-08-2015-0072

Nguyen, H. C. (2017). Impact of international accreditation on the emerging quality assurance system: The Vietnamese experience. Change Management: An International Journal, 17(3), 1-9. https://doi.org/10.18848/2327-798X/CGP/ v17i03/1-9

Nguyen, N. (2018). Transnational education in the Vietnamese market: Paradoxes and possibilities. In L. T. Tran \& S. Marginson (Eds.), Internationalisation in Vietnamese Higher Education (pp. 77-98). Cham: Springer. https://doi.org/10.1007/9783-319-78492-2_5

Nguyen, N., \& Tran, L. T. (2018). Looking inward or outward? Vietnam higher education at the superhighway of globalization: 
Lam, P. Q., Tuan, V. V., \& Duong, T. T. (2020). Improve teaching capacity at private universities in Ho Chi Minh city, Vietnam according to AUN-QA, International Journal of Cognitive Research in Science, Engineering and Education (IJCRSEE), 8(3), 61-72.

Culture, values and changes. Journal of Asian Public Policy, 11(1), 28-45. https://doi.org/10.1080/17516234.2017.13 32457

Nhan, T. T., \& Nguyen, H. C. (2018). Quality challenges in transnational higher education under profit-driven motives: The Vietnamese experience. Issues in Educational Research, 28(2), 138-152. Retrieved from http://www.iier.org.au/iier28/ nhan.pdf

Nhat, N. T. T., \& Bich, P. T. (2017). Higher education massification and quality assurance in Vietnam: A case study of Viet Nam National University Ho Chi Minh City. In: D. Neubauer \& C. Gomes (Eds.), Quality Assurance in Asia-Pacific Universities (pp. 91-108). Cham: Palgrave Macmillan. https://doi.org/10.1007/978-3-319-46109-0_6

Orakcı, S., Dilekli, Y., \& Erdağ, C. (2020). The structural relationship between accountability felt and responsible teaching in Turkish teachers: The mediating effect of innovative thinking. Thinking Skills and Creativity, 36, 100662. https://doi. org/10.1016/j.tsc.2020.100662

Pham, A. (2018a). Employers' perspectives on Vietnamese returnee students. In L. T. Tran \& S. Marginson (Eds.), Internationalisation in Vietnamese Higher Education. Dordrecht: Springer. https://doi.org/10.1007/978-3-319-784922_11

Pham, H. (2018b). International students' choice of destinations for overseas study: A specific push-pull model for Vietnam. In L. T. Tran \& S. Marginson (Eds.), Internationalisation in Vietnamese Higher Education. Dordrecht: Springer. https://doi. org/10.1007/978-3-319-78492-2_9

Pham, L. (2018c). International students' aspirations to contribute to socioeconomic development in Vietnam. In L. T. Tran \& S. Marginson (Eds.), Internationalisation in Vietnamese Higher Education. Dordrecht: Springer. https://doi. org/10.1007/978-3-319-78492-2 10

Pham, T. L. (2017). University governing boards: A view from a corporate perspective. Educational Review, 137, 6-11.

Pitiyanuwat, S., Sujiva, S., \& Pitiyanuwat, T. (2017). Chapter 10 - The rise of quality assurance in Thailand. In M. Shah \& Q. T. N. Do (Eds.), The Rise of Quality Assurance in Asian Higher Education (pp. 161-171). Chandos Publishing. https://doi. org/10.1016/B978-0-08-100553-8.00010-0

Rizkallah, E., \& Seitz, V. (2017). Understanding student motivation: a key to retention in higher education. Annals of the Alexandru loan Cuza University - Economics, 64, 4-13. https://doi.org/10.1515/aicue-2017-0004

Salmi, J. (2018). Social dimension within a quality oriented higher education system. In A. Curaj, L. Deca, \& R. Pricopie (Eds), European Higher Education Area: The Impact of Past and Future Policies (pp. 141-154). Springer. https://doi. org/10.1007/978-3-319-77407-7_10

Sánchez, A., \& Singh, A. (2018). Accessing higher education in developing countries: Panel data analysis from India, Peru, and Vietnam. World Development, 109, 261-278. https://doi.org/10.1016/j.worlddev.2018.04.015

Shah, M., \& Nair, S. (2016). A global perspective on private higher education. Cambridge, UK: Elsevier Publishing.

Thuy Thi, T., \& Yi-Fang, L. (2014). Stakeholders' perspectives on quality assurance in Vietnamese higher education. Higher Education Evaluation and Development, 8(2), 1-30. https://doi.org/10.6197/HEED.2014.0802.01

Tran, D. N. (2018). Impacts of international organizations on Vietnam's higher education policy: The good, the bad and the ugly. In L. T. Tran \& S. Marginson (Eds.), Internationalisation in Vietnamese Higher Education. Dordrecht: Springer. https:// doi.org/10.1007/978-3-319-78492-2_6

Tran, L. T., \& Marginson, S. (2018a). Internationalisation of Vietnamese higher education: An overview. In L. T. Tran \& S. Marginson (Eds.), Internationalisation in Vietnamese Higher Education (pp. 1-17). https://doi.org/10.1007/978-3-319$78492-21$

Tran, L. T., \& Marginson, S. (2018b). Internationalisation of Vietnamese higher education: Possibilities, challenges and implications. In L. T. Tran \& S. Marginson (Eds.), Internationalisation in Vietnamese Higher Education. Dordrecht: Springer. https://doi.org/10.1007/978-3-319-78492-2 14

Tran, L. T., \& Nguyen, H. T. (2018). Internationalisation of higher education in Vietnam through English medium instruction (EMI): Practices, tensions and implications for local language policies. In I. Liyanage (Ed.), Multilingual Education Yearbook 2018 (pp. 91-106). Cham: Springer. https://doi.org/10.1007/978-3-319-77655-2_6

Tran, L. T., Ngo, M., Nguyen, N., \& Dang, X. T. (2017). Hybridity in Vietnamese universities: An analysis of the interactions between Vietnamese traditions and foreign influences. Studies in Higher Education, 42(10), 1899-1916. https://doi.or g/10.1080/03075079.2017.1376872

Van Khai, P. (2005). Government Resolution No. 14/2005/NQ-CP, dated November 2, 2005 "On substantial and comprehensive renewal of Vietnam's tertiary education in the 2006-2020 period". Retrieved from http://vbpl.vn/TW/Pages/vbpqentoanvan.aspx?ItemID=6439

Westerheijden, D. F., Cremonini, L., \& Empel, R. (2010). Accreditation in Vietnam's higher education system. In G. Harman, M. Hayden \& T. Nghi Pham (Eds.), Reforming Higher Education in Vietnam (Vol. 29, pp. 182-195). Dordrecht: Springer. https://doi.org/10.1007/978-90-481-3694-0 13

Yang, R. (2017). Internationalization of higher education in China: A national scenario. In H. de Wit, J. Gacel-Ávila, E. Jones \& N. Jooste (Eds.), The Globalization of Internationalization: Emerging Voices and Perspectives (pp. 142-152). Oxon: Routledge. 